\title{
Production of siderophore type chelates by mixed bacterioplankton populations in nutrient enriched seawater incubations
}

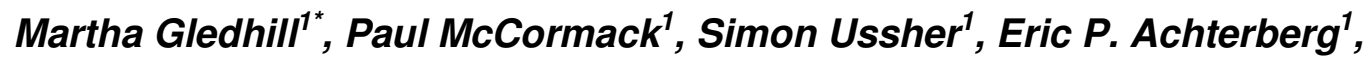
R. Fauzi C. Mantoura ${ }^{2}$ and Paul J. Worsfold ${ }^{1}$

1 School of Earth, Ocean and Environmental Sciences, University of Plymouth, Plymouth, PL4 8AA, UK

2 International Atomic Energy Agency, 4 Quai Antoine 1er, BP No 800, MC 98012 Monaco, Principality of Monaco

${ }^{*}$ corresponding author

\section{Abstract}

Siderophore type chelates were isolated from nutrient enriched seawater collected from coastal and near shore environments and detected using a novel high performance liquid chromatography - electrospray ionisation mass spectrometric technique. Seawater was enriched with added glucose, ammonia and phosphate, and incubated for four days. Seven different siderophore type compounds were detected in the extracted supernatants and tentatively identified based on mass numbers and spectra. The compounds comprised two groups, the ferrioxamines and the amphibactins. They were produced at typical coastal iron concentrations (total dissolved iron $=2.9 \pm 1.4$ 
$\mathrm{nM}$ and $2.2 \pm 0.1 \mathrm{nM}$ ) both in the presence and absence of the iron chelating ligand ethylene diamine- $\mathrm{N}, \mathrm{N}^{\prime}$-diacetic acid.

\section{Keywords}

Iron, siderophores, chelates, ferrioxamines, amphibactins, HPLC-ESI-MS, coastal waters

\section{Introduction}

Iron is an essential trace nutrient which limits primary productivity in oceanic high nutrient low chlorophyll areas and thus influences the biological carbon pump and marine biodiversity (Falkowski et al., 1998). Heterotrophic bacterioplankton play an important role in the biological carbon pump, as they are involved in the cycling of nutrients and production of carbon dioxide (Tortell et al., 1996). Bacterioplankton account for up to $70 \%$ of the total iron uptake in open ocean regions (Tortell et al., 1996; Maldonado and Price, 1999) and have higher iron to carbon ratios than phytoplankton (Tortell et al., 1996). Iron limitation of bacterial productivity is the subject of debate (Pakulski et al., 1996; Kirchman et al., 2000), however it is known that in order to aid iron acquisition, some heterotrophic bacteria produce siderophores, which are high affinity iron(III) binding ligands (Neilands, 1995). Several marine siderophores have been characterised (Trick et al., 1983; Haygood et al., 1993; Reid et al., 1993; Martinez et al., 2000; Martinez et al., 2001; Martinez et al., 2003), and their production is ubiquitous in marine bacterial isolates (Trick, 1989; Trick and Kerry, 1992; Haygood et al., 1993; Soria-Dengg and Reissbrodt, 2001). However the presence of siderophores in seawater has not been directly confirmed, although siderophore type chelating groups have 
been detected in extracts isolated from seawater (Macrellis et al., 2001) and siderophores are known to have similar binding strengths to natural ligands detected in seawater (Rue and Bruland, 1995; Lewis et al., 1995; van den Berg, 1997; Gledhill et al., 1998; Witter et al., 2000).

A high proportion of the marine siderophores characterised to date are reported to have high cellular membrane affinities or are produced by bacteria associated with particles (Haygood et al., 1993; Martinez et al., 2000; Martinez et al., 2001; Xu et al., 2002; Martinez et al., 2003). Siderophores produced in these diffusively limited micro - environments are hypothesised to act as a source to the bulk aqueous phase (Haygood et al., 1993; Martinez et al., 2003) and consequently play a role in oceanic iron biogeochemistry. Siderophores enhance the solubility of iron in marine waters, and alter iron bioavailability to other marine organisms (Hutchins et al., 1999). Siderophore production is reportedly only induced under conditions of low iron availability (Neilands, 1995). Whilst concentrations of dissolved iron in the ocean vary over three orders of magnitude from $0.05 \mathrm{nM}$ in open ocean regions (Martin and Gordon, 1988) to $5 \mathrm{nM}$ or more in coastal waters (Bowie et al., 2002), it is not known what iron concentration is low enough to trigger siderophore production. Therefore the significance of siderophore production in various oceanic systems (e.g. open, upwelling and coastal) is unknown. The investigation of siderophores in the marine environment has been hindered by a lack of sensitive and specific analytical techniques (McCormack et al., 2003). This manuscript reports the application of a newly developed method (McCormack et al., 2003) to the detection of unknown siderophore type chelates produced by coastal bacterioplankton in nutrient (carbon, nitrogen, 
phosphorus) enriched seawater incubations in the presence and absence of an added chelating agent.

\section{Experimental}

\subsection{Seawater sampling and incubation conditions.}

Seawater was sampled on 6 October 2002 in Wembury Bay $\left(50^{\circ} 18.9^{\prime} \mathrm{N}\right.$, $\left.4^{\circ} 5.9^{\prime} \mathrm{W}\right)$ and on 16 December 2002 from station L4 $\left(50^{\circ} 15.8^{\prime} \mathrm{N}, 4^{\circ} 12.55^{\prime} \mathrm{W}\right)$ in the English Channel during a survey with the R.V. Squilla. Seawater was collected in acid washed (1 M hydrochloric acid), $500 \mathrm{~mL}$ autoclaved polycarbonate culture bottles (Nalgene). The samples were refrigerated overnight and then four $500 \pm 20 \mathrm{~g}$ aliquots were enriched with $9 \times 10^{-3} \mathrm{M}$

glucose, $2 \times 10^{-4} \mathrm{M}$ ammonium chloride and $2 \times 10^{-5} \mathrm{M}$ potassium dihydrogen phosphate. Glucose, ammonium chloride and potassium dihydrogen phosphate solutions had previously been cleaned with Chelex 100 (Sigma) (Price et al., 1988) in order to reduce iron contamination, and then filter sterilized (0.2 $\mu \mathrm{m}$, Minisart). Fifty $\mu \mathrm{M}$ ethylene diamine- $N, N^{\prime}$-diacetic acid (EDDA, filter sterilized) was added to two aliquots to ensure that the free iron concentrations were buffered to low levels. The seawater was incubated at 15 ${ }^{\circ} \mathrm{C}$ on a $12 \mathrm{~h}$ on / $12 \mathrm{~h}$ off light cycle with regular shaking for 4 days. For the Wembury incubations, bacterial growth was monitored using absorbance at $600 \mathrm{~nm}$, while for the L4 incubations, bacterial numbers were determined at the end of the experiment using the acridine orange method (Turley, 1993). Following the incubation period, a $100 \mathrm{~mL}$ aliquot was filtered $(0.45 \mu \mathrm{m}$, cellulose acetate, Whatman) for the determination of dissolved iron (Achterberg et al., 2001) while $350 \mathrm{~mL}$ was centrifuged (9000 g, $20 \mathrm{~min}$ ) for 
the determination of siderophore type chelates in the incubation supernatant. The Wembury incubation supernatants were also filtered $(0.2 \mu \mathrm{m}, 47 \mathrm{~mm}$ cellulose acetate, Whatman) using a Solvac filtration unit. Three hundred $\mathrm{mL}$ of each incubation was used for the extraction.

\subsection{Solid Phase Extraction.}

Siderophore type chelates were extracted from the aqueous phases using polystyrene divinyl benzene SPE cartridges (Isolute ENV+, $100 \mathrm{mg} \times 3 \mathrm{~mL}$, International Sorbent Technology Ltd)(McCormack et al., 2003). Cartridges were cleaned with $1 \mathrm{~mL}$ methanol and $1 \mathrm{~mL} 11.2 \mathrm{mM}$ ammonium carbonate $(\mathrm{pH} 7.5)$ prior to extraction of siderophore type chelates at a flow rate of $3 \mathrm{~mL}$ $\mathrm{min}^{-1}$. Cartridges were washed with $1 \mathrm{~mL}$ of $11.2 \mathrm{mM}$ ammonium carbonate and siderophore type chelates eluted with $5 \mathrm{~mL}$ of 1:20:80 (volume: volume: volume) formic acid: water: methanol. The eluent was reduced to approximately $600 \mu \mathrm{L}$ under nitrogen immediately prior to analysis by HPLCESI-MS.

\subsection{Instrumental analysis and chemicals}

High performance liquid chromatography was carried out using a binary pump (P580A, Dionex-Softron GmbH). Separations were performed using a polystyrene divinyl benzene stationary phase (PRP-1, $100 \times 2.1 \mathrm{~mm}, 3 \mu \mathrm{m}$, Hamilton). The mobile phases were $0.1 \%(\mathrm{v}: \mathrm{v})$ aqueous formic acid $(\mathrm{A})$ and methanol (B). Methanol was modified by the addition of $0.1 \%(\mathrm{v}: \mathrm{v})$ formic acid to avoid changes in $\mathrm{pH}$ during gradient elution. A standard gradient of $95 \% \mathrm{~A}$ : $5 \%$ B to $100 \%$ B in $20 \mathrm{~min}$, followed by $10 \mathrm{~min}$ isocratic elution with $100 \% \mathrm{~B}$ 


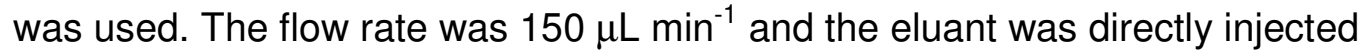
into the mass spectrometer. Five $\mu \mathrm{L}$ sample injections were suction loaded into a PEEK sample loop via a metal free manual injector (9125, Rheodyne). Mass spectrometry analysis was carried out using an ion trap mass spectrometer fitted with an electrospray interface (ThermoQuest Finnigan Mat LCQ). Data were acquired and processed with Xcalibur 1.0 software. Instrument tuning and mass calibration were carried out and checked using the automatic calibration procedure and standard calibration solutions. The following instrument parameters were used: source voltage, $+4.5 \mathrm{kV}$; capillary voltage $+20 \mathrm{~V}$; tube lens offset, $+10.00 \mathrm{~V}$; capillary temperature, $220{ }^{\circ} \mathrm{C}$; nitrogen sheath gas flow rate, 60 (arbitrary units) and nitrogen auxiliary gas flow rate 20 (arbitrary units). MS/MS was carried out by bombarding selected ions with helium atoms using an excitation energy of $35 \%$. Mass spectra were recorded in the positive ion mode within $\mathrm{m} / \mathrm{z} 300-1500$. Peak areas were measured after extracting \pm 0.5 mass units of the $\mathrm{H}^{+}$and $\mathrm{Na}^{+}$adducts from the total ion current.

Ultra pure water was obtained from a Milli-Q water purification system (Millipore). All solvents and modifiers used were HPLC grade. Methanol, formic acid and iron(III) chloride were obtained from VWR. Ferrioxamine B (as deferoxamine mesylate) was obtained from Sigma. All other reagents were purchased from Fisher Scientific. A $1 \mathrm{mg} \mathrm{mL}^{-1}$ aqueous stock solution of iron free ferrioxamine was made up and stored at $4^{\circ} \mathrm{C}$. The iron(III) complex was prepared by a 2 molar equivalent addition of a freshly prepared $10 \mathrm{mM}$ iron(III) chloride standard and ten times diluted with water. Working standards were prepared by dilution in water of the required volumes. A stock solution of 1.4 
M gallium in $1 \%$ nitric acid (VWR) was used to identify siderophore type chelates in the sample (McCormack et al., 2003).

\section{Results and Discussion}

\subsection{Identification of known and unknown siderophore type chelates} Analyses were undertaken with a recently developed HPLC-ESI-MS technique, which is capable of separating and detecting multiple hydroxamate type siderophores present at low concentrations $(\mathrm{nM})$ in seawater (McCormack et al., 2003). Siderophore type coumpounds were identified by re-analysing the sample after addition of excess (14 mM) gallium. Gallium complexes of these compounds were detected in the chromatograms by their distinctive mass spectra which reflect the abundance ratio of the naturally occurring gallium isotopes $\left({ }^{69} \mathrm{Ga}:{ }^{71} \mathrm{Ga}\right.$ ratio $\left.3: 2\right)$. Extracted mass chromatograms for the gallium complexes for Wembury and L4 incubations are shown in Figure 1. In this paper we describe these compounds as siderophore type chelates, as they are biologically produced, complex iron (see below) and have similar molecular weights to siderophores. A total of seven siderophore type chelates, labelled $A$ to $G$, were identified in the Wembury incubations and four, labelled D to $G$, in the L4 incubations. Once identified, original sample chromatograms were examined for the presence of the complexed and apo (uncomplexed) forms of these chelates by extracting mass chromatograms using expected $\mathrm{m} / \mathrm{z}$ ratios. Retention times and mass: charge $(\mathrm{m} / \mathrm{z})$ ratios for apo, iron and aluminium (see section 3.3) complexes are listed in Table 1. The chromatographic behaviour of the siderophore type 
chelates found in the Wembury incubations were of two main types, with the first group (A-C) eluting between 7 and 9 minutes, and the second group (DG) eluting between 20 and 24 minutes. Chelates D-G in the Wembury and L4 incubations were identified as the same compounds by their $\mathrm{m} / \mathrm{z}$ ratios and retention times.

Further structural information was gained and identities allocated after MS/MS of the chelates. Chelates $A-C$ were identified as ferrioxamines and chelates D-G as amphibactins (Table 1). Structures of the previously characterised ferrioxamines and amphibactins are given in Figure 2 (Matzanke, 1991; Martinez et al., 2003). In most cases the allocated identities are tentative, and are based on $\mathrm{m} / \mathrm{z}$ ratios and compatible fragmentation pathways. The occurrence of chelates $A(\mathrm{~m} / \mathrm{z} 614$, ferrioxamine $B)$ and $C(\mathrm{~m} / \mathrm{z}$ 672, ferrioxamine $\mathrm{G}$ ) in the Wembury incubations has been reported previously (McCormack et al., 2003). In addition, a further unknown siderophore type chelate $(\mathrm{B})$ eluting in this range was identified. A ferrioxamine with this molecular mass (apo form $\mathrm{m} / \mathrm{z} 605$ ) has not previously been reported in the literature. It differed from chelate C by a methyl group, and from chelate A by the addition of a carboxylate group. The fragmentation pathway on MS/MS (Figure 3a) indicated a close association with chelate C, as the major daughter ion for both compounds was obtained through the loss of the terminal carboxylate group.

Siderophore type chelates D-G were tentatively identified as belonging to the amphibactin series of siderophores (Martinez et al., 2003). Fragmentation pathways for both complexed and uncomplexed chelates proceeded via the loss of a terminal hydroxamate chelating group, as shown 
for chelate $\mathrm{F}$ in Figure $3 \mathrm{~b}$. The masses of the chelates differed by the extension of saturated or unsaturated carbon chains (i.e. $E=D+\mathrm{C}_{2} \mathrm{H}_{2}, \mathrm{~F}=\mathrm{D}$ $+\mathrm{C}_{2} \mathrm{H}_{4}$ and $\left.\mathrm{G}=\mathrm{D}+\mathrm{C}_{4} \mathrm{H}_{6}\right)$. Siderophore type chelates $\mathrm{F}$ and $\mathrm{G}$ of this series had the same $\mathrm{m} / \mathrm{z}$ ratios as amphibactin $D$ and $E$ respectively, chelate $E$ falls within the mass range reported previously for amphibactins $(\mathrm{m} / \mathrm{z}$ 816-902, (Martinez et al., 2003)) while chelate $\mathrm{D}$ had a lower $\mathrm{m} / \mathrm{z}$ ratio than the amphibactins reported previously (Martinez et al., 2003). The amphibactins reported by Martinez et al. (2003) were extracted from cell membranes using a more lipophilic solvent (ethanol), whilst the siderophore type chelates isolated in this study were in the dissolved phase, perhaps explaining the different distributions of chelates observed. These results indicate that even chelates with high membrane affinities such as amphibactins may be important complexants in the dissolved phase.

The siderophore type chelates produced in these experiments are likely to be a reflection of both the original sample location and the incubation conditions used for the experiment. Both amphibactins and ferrioxamine $\mathrm{G}$ have recently been isolated and characterised from marine bacterial species belonging to the Vibrio genus (Martinez et al., 2001; Martinez et al., 2003), a group of gram negative bacteria, which are able to preferentially exploit the incubation conditions used in these experiments (Fuchs et al., 2000). Furthermore, ferrioxamine $\mathrm{G}$ was isolated from a particle associated bacteria (strain BLI-41 (Martinez et al., 2001)), while amphibactins were isolated from a near shore isolate (strain R-10 (Martinez et al., 2003)). As the Wembury sample was collected near the shore, the abundance of particles and thus particle associated bacteria was likely to be higher than for sample $L 4$, 
possibly explaining why the ferrioxamines were observed in the Wembury but not the L4 incubations.

\subsection{Abundance of iron complexed and apo forms of siderophores.}

In order to investigate the influence of the concentration and availability of iron on the production of siderophore type chelates, incubations were carried out in the presence and absence of EDDA. This was used as an iron buffering ligand instead of ethylenediaminetetraacetic acid (EDTA), as EDTA has been reported to cause excessive interference with the iron metabolism in bacteria (Cox, 1994). Concentrations of dissolved iron in the filtered $(0.45 \mu \mathrm{m}$ pore size) supernatant at the end of the experiments were $2.9 \pm 1.4 \mathrm{nM}$ and $2.2 \pm$ $0.1 \mathrm{nM}$ for Wembury and L4 incubations respectively. Bacterial growth was not significantly different between the +EDDA and - EDDA treatments in the experiments. The UV absorbance at the end of the Wembury experiment was $87 \pm 5$ a.u., while bacterial counts in the L4 incubations were $3.3 \pm 0.6 \times 10^{13}$ cells $\mathrm{ml}^{-1}$. Critical stability constants for the complexation of the major seawater ions and iron by EDDA are not available in the literature, and furthermore natural iron complexing ligands in the seawater samples were not measured, so iron speciation in the incubations could not be modelled. However, +EDDA incubations were assumed to have a lower free iron availability than the -EDDA incubations. The concentration of ferrioxamine B (the iron complexed form) in the extracted Wembury samples was estimated from standard calibrations to be ca. $30 \mathrm{nM}$ in the +EDDA incubations and ca. $4 \mathrm{nM}$ in the -EDDA incubations. Using a preconcentration factor of 500 and an extraction efficiency of $21 \%$ (McCormack et al., 2003), this leads to an 
estimated concentration of $0.3 \mathrm{nM}$ in the +EDDA incubation and $0.04 \mathrm{nM}$ in the -EDDA incubation for ferrioxamine B. Quantification of other siderophore type chelates detected was not possible as different siderophores have different detector sensitivities (Gledhill, 2000; McCormack et al., 2003) and standards were unavailable.

Production of siderophore type chelates was observed in both experiments in the presence and absence of EDDA (Figure 4). Thus, in both Wembury and L4 incubation experiments, siderophores were produced at typical coastal iron concentrations and in the absence of EDDA. Complexation of iron by chelates such as siderophores has significance not only to bacterial productivity, but also to other organisms within the marine environment, most importantly phytoplankton. Iron complexed to siderophores is generally thought to be unavailable for uptake by phytoplankton (Hutchins et al., 1999), although iron stressed phytoplankton have been reported to extracellularly reduce iron bound to ferrioxamine type siderophores prior to uptake (Maldonado and Price, 1999). Recent work has also shown that siderophores are involved in the photochemically induced redox cycling of iron, although tris hydroxamate siderophores were not found to be photochemically active (Barbeau et al., 2001; Barbeau et al., 2003). Thus, although siderophores may not be available for direct uptake by phytoplankton, they may raise iron availability through increasing the dissolved fraction of iron and enhancing the photochemical production of the more readily available iron(II).

Differences were observed in the abundances of the apo and iron complexed forms of the siderophore type chelates in the absence and presence of EDDA, reflecting the difference in iron availability between the 
two treatments. For the Wembury incubations, the abundances of chelates AC were higher in the +EDDA incubations while the abundances of chelates DG were higher in the -EDDA incubations. For L4, the abundances of chelates D-G were higher in the +EDDA than in the -EDDA incubations. An increased abundance of siderophore type chelates in the presence of EDDA is compatible with the hypothesis that these chelates are produced in response to low iron stress. However results for chelates D-G in the Wembury incubations would appear to contradict this hypothesis, as these chelates were more abundant in the absence of EDDA. This could be indicative of a competitive interaction between different bacteria, resulting from differences in the affinities of different chelates for iron. The conditional stability constant for the complexation of iron with ferrioxamine $\mathrm{B}$ in seawater ( $\left.\mathrm{K}_{\mathrm{L} / \mathrm{Fe}^{\prime}}\right)$ has been calculated to be $10^{16.5} \mathrm{M}^{-1}$ (Rue and Bruland, 1995), which compares with a $\mathrm{K}_{\mathrm{L} / \mathrm{Fe}^{\prime}}$ of $10^{12.2} \mathrm{M}^{-1}$ measured for aquachelins (Barbeau et al., 2001), siderophores which are structurally similar to the amphibactins. Thus the bacteria producing chelates D-G may not have been able to compete effectively for iron with the bacteria producing chelates A-C in the presence of EDDA.

\subsection{Identification of aluminium siderophore complexes}

In addition to the iron and apo forms of the siderophores, aluminium complexes were also observed in the chromatograms (Table 1, Figure 5).

Siderophores are known to have a high affinity for metals other than iron, which have $\mathrm{a}+3$ oxidation state, although the affinity of ferrioxamine $\mathrm{B}$ for $\mathrm{A} \mathrm{I}^{3+}$ is 6 orders of magnitude lower than for $\mathrm{Fe}^{3+}\left(\log \mathrm{K}_{\mathrm{Fe}(\mathrm{III})}=30.6, \log \mathrm{K}_{\mathrm{Al}}=\right.$ 
24.1(Martell and Smith, 1998)). The aluminium complexes of the siderophore type chelates followed a similar trend to those for the apo and iron complexed forms, with higher abundancies in the +EDDA incubations for chelates A-C in the Wembury samples, and E-G in the L4 samples. To our knowledge this is the first reported evidence for complexation of aluminium by naturally occurring organic ligands in the marine environment. However, given the differences in affinity of siderophores for iron and aluminium, this is only likely to be significant if the chelate concentration is in excess of the iron concentration.

\section{Conclusions}

Seven different siderophore type chelates have been identified in nutrient enriched incubations of coastal seawaters. One siderophore was positively identified as ferrioxamine $\mathrm{B}$, a further two siderophore type chelates tentatively identified as ferrioxamine $G$ and a related ferrioxamine and four siderophore type chelates identified as belonging to the amphibactin series. Production of siderophore type chelates was affected by the presence of the added iron chelating agent EDDA, probably reflecting iron availability and the ability of different bacterial groups to exploit the culture conditions.

In addition to complexation of iron, the results show that aluminium could also undergo complexation by siderophore type chelates in seawater although this is only likely to occur when chelates are in excess of iron concentrations. Quantification of the significance of iron chelates to the biogeochemical cycling of oceanic iron is an important goal for future studies. 


\section{Acknowledgements}

This work was funded by NERC grant NER/B/S/2000/00764. The authors would like to thank the crew of the RV Squilla. 


\section{References}

Achterberg, E.P., Holland, T.W., Bowie, A.R., Mantoura, R.F.C. and Worsfold, P.J., 2001. Determination of iron in seawater. Anal. Chim. Acta, 442: 1-14.

Barbeau, K., Rue, E.L., Trick, C.G., Bruland, K.T. and Butler, A., 2003.

Photochemical reactivity of siderophores produced by marine heterotrophic bacteria and cyanobacteria based on characteristic Fe(III) binding groups. Limnol. Oceanogr., 48: 1069-1078.

Barbeau, K.A., Rue, E.L., Bruland, K.W. and Butler, A., 2001. Photochemical cycling of iron in the surface ocean mediated by microbial iron(III)-binding ligands. Nature, 413: 409-413.

Bowie, A.R., Whitworth, D.J., Achterberg, E.P., Mantoura, R.F.C. and Worsfold, P.J., 2002. Biogeochemistry of Fe and other trace elements (Al, Co, $\mathrm{Ni}$ in the upper Atlantic Ocean. Deep-Sea Res. I, 49: 605-636.

Cox, C.D., 1994. Deferration of laboratory media and assays for ferric and ferrous ions. Methods in Enzymology, 235: 315-372.

Falkowski, P.G., Barber, R.T. and Smetacek, V., 1998. Biogeochemical controls and feedbacks on ocean primary productivity. Science, 281: 200-206. 
Fuchs, B.M., Zubkov, M.V., Sahm, K., Burkill, P.H. and Amann, R., 2000. Changes in community composition during dilution cultures of marine bacterioplankton as assessed by flow cytometric and molecular biological techniques. Environ. Microbiol., 2: 191-201.

Gledhill, M., 2000. Electrospray lonisation - Mass Spectrometry of Hydroxamate siderophores. Analyst, 126: 1359-1362.

Gledhill, M., van den Berg, C.M.G., Nolting, R.F. and Timmermans, K.R., 1998. Variability in the speciation of iron in the northern North Sea. Mar. Chem., 59: 283-300.

Haygood, M.G., Holt, P.D. and Butler, A., 1993. Aerobactin production by a planktonic marine Vibrio sp. Limnol. Oceanogr., 38: 1091-1097.

Hutchins, D.A., Witter, A.E., Butler, A. and Luther III, G.W., 1999. Competition among marine phytoplankton for different chelated iron species. Nature, 400: 858-861.

Kirchman, D.L., Meon, B., Cottrell, M.T., Hutchins, D.A., Weeks, D. and Bruland, K.W., 2000. Carbon versus iron limitation of bacterial growth in the Californian upwelling regime. Limnol. Oceanogr., 45: 1681-1688.

Lewis, B.L., Holt, P.D., Taylor, S.W., Wilhelm, S.W., Trick, C.G., Butler, A. and Luther III, G.W., 1995. Voltammetric estimation of iron (III) thermodynamic 
stability constants for chatecholate siderophores isolated from marine bacteria and cyanobacteria. Mar. Chem., 50: 179-188.

Macrellis, H.M., Trick, C.G., Rue, E.L., Smith, G. and Bruland, K., 2001.

Collection and detection of natural iron-binding ligands from seawater. Mar. Chem., 76: 175-187.

Maldonado, M.T. and Price, N.M., 1999. Utilization of iron bound to strong organic ligands by plankton communities in the subarctic Pacific Ocean. Deep-Sea Res. II, 46: 2447-2473.

Martell, A.E. and Smith, R.M., 1998. Critically selected stability constants of metal complexes version 5.0. University College Station, TX, Texas A \& M University.

Martin, J.H. and Gordon, R.M., 1988. Northeast Pacific iron distributions in relation to phytoplankton productivity. Deep Sea Res., 35: 177-196.

Martinez, J.S., Carter-Franklin, J.N., Mann, E.L., Martin, J.D., Haygood, M.G. and Butler, A., 2003. Structure and membrane affinity of a suite of amphiphilic siderophores produced by a marine bacterium. Proc. Nat. Acad. Sci., USA, 100: 3754-3759.

Martinez, J.S., Haygood, M.G. and Butler, A., 2001. Identification of a natural desferrioxamine siderophore produced by a marine bacterium. Limnol. Oceanogr., 46: 420-424. 
Martinez, J.S., Zhang, G.P., Holt, P.D., Jung, H.-T., Carrano, C.J., Haygood, M.G. and Butler, A., 2000. Self-assembling amphiphilic siderophores from marine bacteria. Science, 287: 1245-1247.

Matzanke, B.F., 1991. Structures, coordination chemistry and functions of microbial iron chelates. In:Winkelmann, G., (Editor), CRC Handbook of microbial chelates. CRC Press Inc, Boca Raton, pp. 15-65.

McCormack, P., Worsfold, P.J. and Gledhill, M., 2003. Separation and detection of siderophores produced by marine bacterioplankton using highperformance liquid chromatography with electrospray ionization mass spectrometry. Anal. Chem., 75: 2647-2652.

Neilands, J.B., 1995. Siderophores: structure and function of microbial iron transport compounds. J. Biol. Chem., 270: 26723-26726.

Pakulski, J.D., Coffin, R.B., Kelley, C.A., Holder, S.L., Downer, R., Aas, P., Lyons, M.M. and Jeffrey, W.H., 1996. Iron stimulation of antarctic bacteria. Nature, 383: 133-134.

Price, N.M., Harrison, G.I., Hering, J.G., Nirel, P.M.V., Palenik, B. and Morel, F.M.M., 1988. Preparation and chemistry of the artificial algal culture medium Aquil. Biol. Oceanogr., 6: 443-461. 
Reid, R.T., Live, D.H., Faulkner, D.J. and Butler, A., 1993. A siderophore from a marine bacterium with an exceptional ferric ion stability constant. Nature, 366: 455-457.

Rue, E.L. and Bruland, K.W., 1995. Complexation of iron(III) by natural organic ligands as determined by a new competitive equilibration/adsorptive cathodic stripping voltammetry method. Mar. Chem., 50: 117-139.

Soria-Dengg, S. and Reissbrodt, R.a.H.U., 2001. Siderophores in marine coastal waters and their relevance for iron uptake by phytoplankton: experiments with the diatom Phaeodactylum tricornutum. Mar. Ecol. Prog. Ser., 220: 73-82.

Tortell, P.D., Maldonado, M.T. and Price, N.M., 1996. The role of heterotrophic bacteria in iron-limited ocean ecosystems. Nature, 383: 330332.

Trick, C.G., 1989. Hydroxamate -siderophore production and utilization by marine eubacteria. Curr. Microbiol., 18: 375-378.

Trick, C.G., Anderson, R.J., Gillam, A. and Harrison, P.J., 1983. Prorocentrin: an extracellular siderophore produced by the marine dinoflagellate Prorocentrum minimum. Science, 219: 306-308. 
Trick, C.G. and Kerry, A., 1992. Isolation and purification of siderophores produced by cyanobacteria, Synechococcus sp. PCC 7942 and Anabaena variabilis ATCC 29413. Curr. Microbiol., 24: 241-245.

Turley, C.M., 1993. Direct estimates of bacterial numbers in seawater samples without incurring cell loss due to sample storage. In:Kemp, P.F., Sherr, B.F., Sherr, E.B. and Cole, J.J., (Editors), Handbook of methods in aquatic microbial ecology. Lewis Publishers, Boca Raton, pp. 143-147.

van den Berg, C.M.G., 1997. Evidence for organic complexation of iron in seawater. Mar. Chem.

Witter, A.E., Hutchins, D.A., Butler, A. and Luther III, G.W., 2000.

Determination of conditional stability constants and kinetic constants for strong model Fe-binding ligands in seawater. Mar. Chem., 69: 1-17.

Xu, G., Martinez, J.S., Groves, J.T. and Butler, A., 2002. Membrane affinity of the amphiphilic marinobactin siderophores. J. Am. Chem. Soc., 124: 1340813415. 
Figure Captions

Figure 1. Extracted mass chromatograms for gallium complexed siderophores identified in supernatants of incubations from a-c) Wembury and d) L4. Extracted masses $(\mathrm{m} / \mathrm{z})$ are given on the figure. $\mathrm{NL}$ : maximum ion count.

Figure 2. Structures of ferrioxamines $B$ and $G$ and amphibactins $D$ and $E$.

Figure 3. Mass spectra obtained on MS/MS analysis of a) siderophore $B(\mathrm{~m} / \mathrm{z}$ 658.4) and b) siderophore $F(m / z$ 885.4). Fragments lost to produce the major daughter ions are shown on the figures.

Figure 4. Abundances of (a) iron(III) and (b) apo siderophores in Wembury incubations. Abundances of (c) iron(III) and (d) apo siderophores in L4 incubations.

Figure 5. Abundances of aluminium complexed siderophores in a) Wembury incubations and b) L4 incubations. 
Table 1. Siderophores identified in the extracted supernatants of nutrient enriched incubated seawaters. Identities are tentative and based on compatible $\mathrm{m} / \mathrm{z}$ and fragmentation pathways obtained after MS/MS of the ions, except for ferrioxamine B, which was compared directly with a known standard (McCormack et al., 2003). n.d. - not detected.

\begin{tabular}{|l|l|l|l|l|l|l|l|}
\hline & & \multicolumn{2}{l|}{ Protonated m/z } & \multicolumn{2}{l|}{ Retention time (mins) } \\
\hline Siderophore & Identity & apo & Fe(III) & Al & apo & Fe(III) & Al \\
\hline A & Ferrioxamine B & 561 & 614 & 585 & n.d. & 8.2 & 7.6 \\
\hline B & $\begin{array}{l}\text { Uncharacterised } \\
\text { ferrioxamine }\end{array}$ & 605 & 658 & 629 & n.d. & 8.7 & 8.3 \\
\hline C & Ferrioxamine G & 619 & 672 & 643 & 10.7 & 8.9 & 8.4 \\
\hline D & Uncharacterised & 804 & 857 & 828 & 20.8 & 21.5 & 21.4 \\
& amphibactin & & & & & & \\
\hline E & Uncharacterised & 830 & 883 & 854 & 21.3 & 22.2 & 22.0 \\
\hline F & amphibactin & & & & & & \\
\hline G & Amphibactin D & 832 & 885 & 856 & 21.5 & 22.5 & 22.1 \\
\hline
\end{tabular}




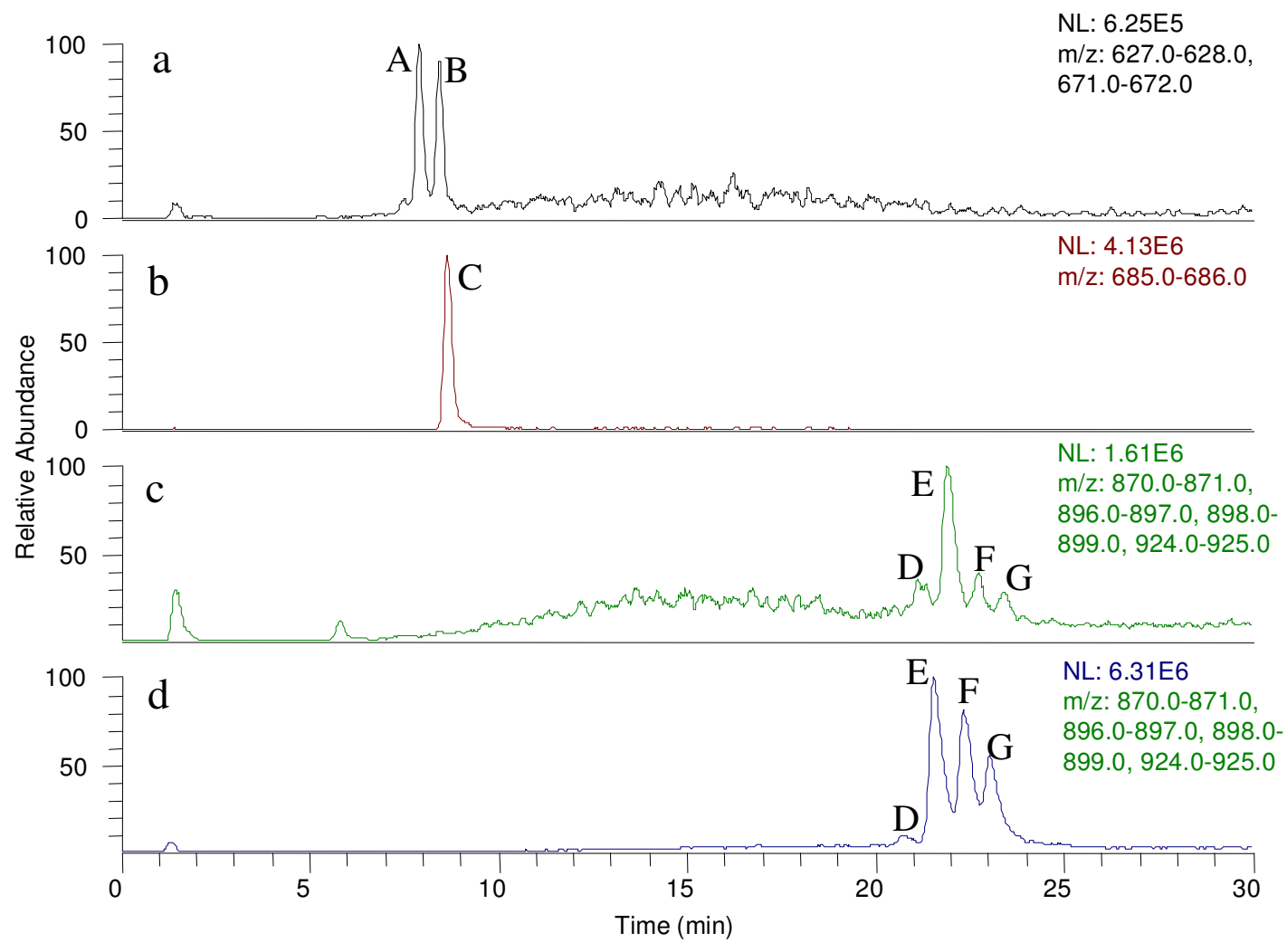

Fig. 1 
Desferrioxamine B

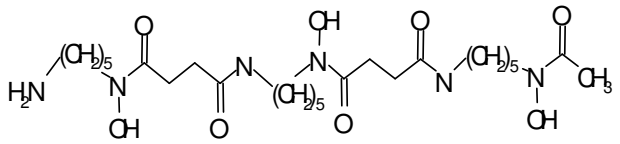

Desferrioxamine G<smiles>CN(C)C(=O)CCC(=O)N(O)ONC(=O)CCC(=O)N(O)[14CH2]N</smiles>

Amphibactins (Martinez et al., 2003a)

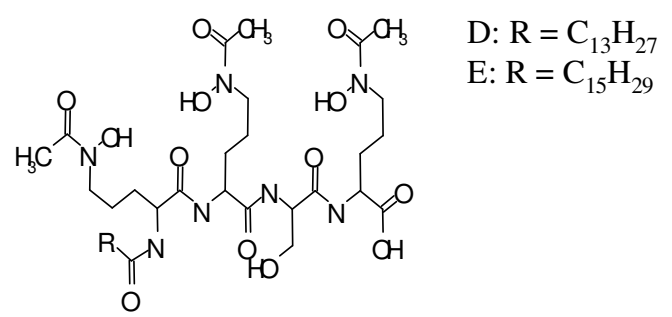

Fig. 2 

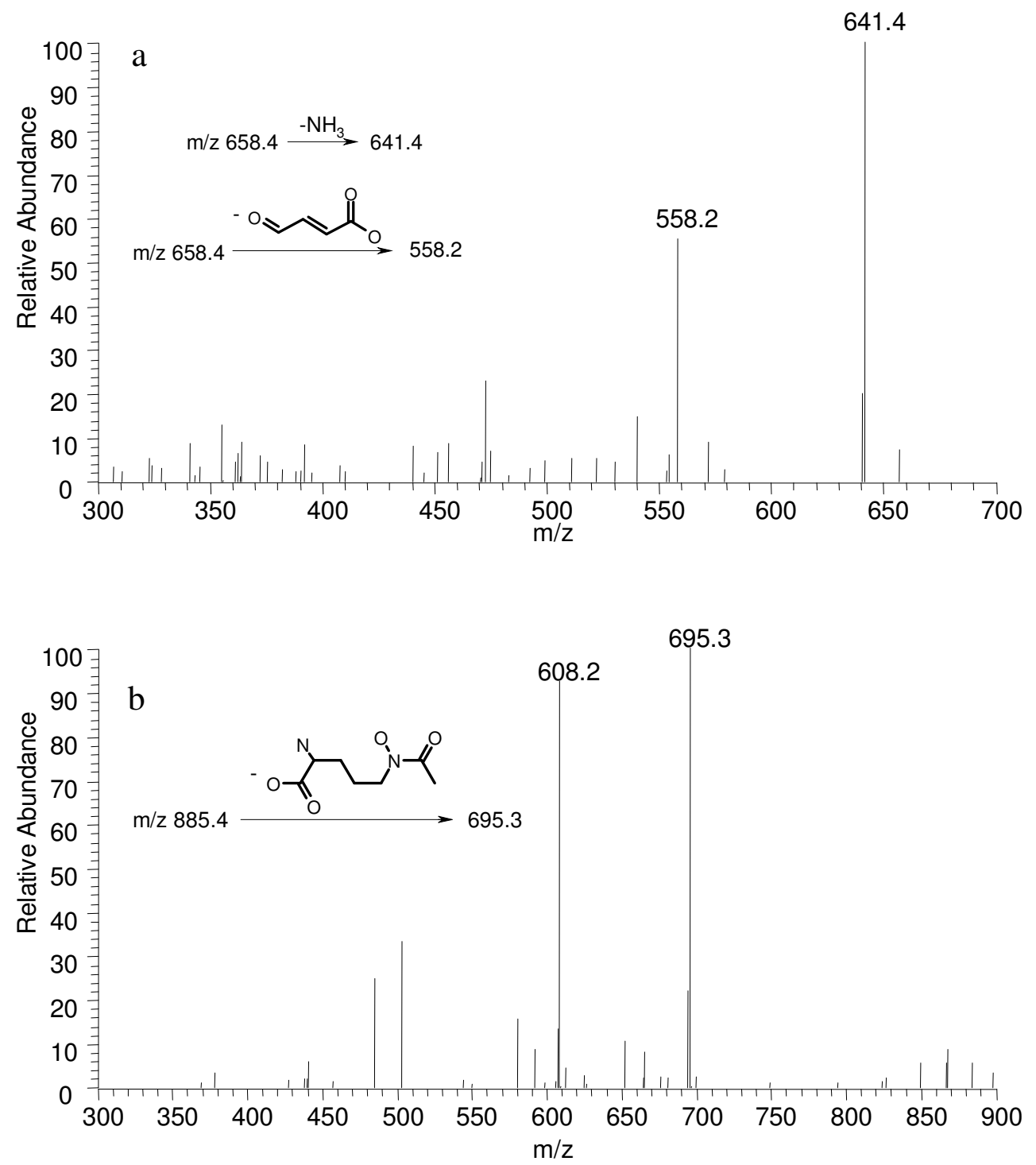

Fig. 3 

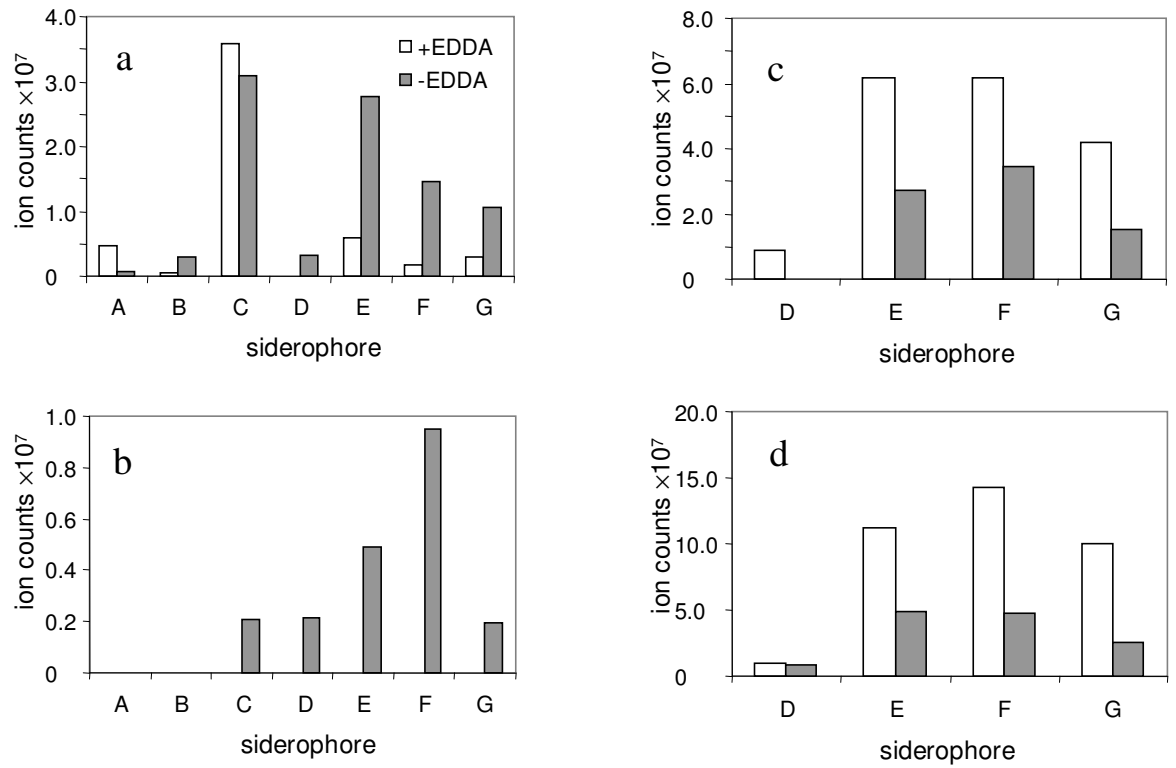

Fig. 4 

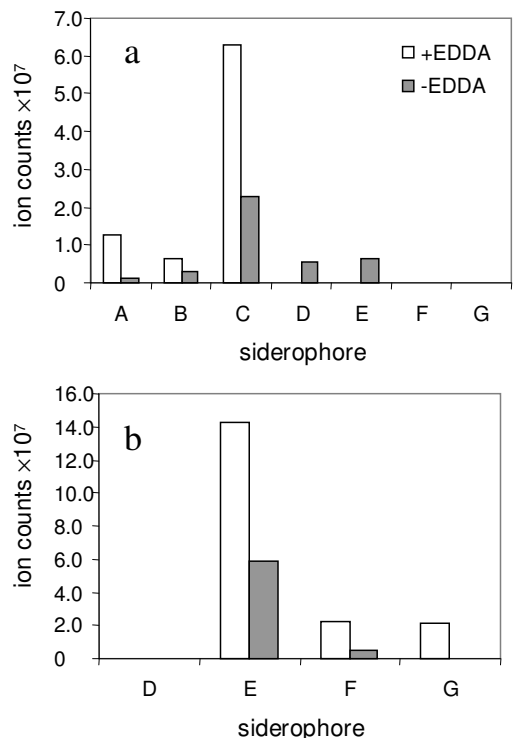

Fig. 5 